\title{
Estimation of Difference in Rate of Healing of Contusions in Diabetic, Hypertensive and Anemic Persons by Subjective and Objective Analyses
}

\author{
Nisha Nandakumar ${ }^{1}$, Prasannan K. ${ }^{2}$, Nisha T.R. ${ }^{3}$ \\ ${ }^{1}$ Assistant Professor, Department of Forensic Medicine and Toxicology, KMCT Medical College, Kozhikode, \\ ${ }^{2}$ Professor And HOD, Department of Forensic Medicine and Toxicology, Govt. Medical College, Kozhikode, \\ Kerala, ${ }^{3}$ Associate Professor, Department of Pathology, Govt. Medical College, Alapuzha, Kerala
}

\begin{abstract}
Background and Objectives: Age of injuries have several medicolegal implications including assault, abuse,criminal conjectures etc. Contusions are wounds characterized by effusion of blood into tissue spaces caused by forceful impact of blunt objects. Its colour changes reflect the natural healing process, though these changes donot occur uniformly and depend on the size of contusion, age and physique of the person and also presence or absence of diseases. This study was aimed at estimating the delay in healing of contusions in diabetic, hypertensive and anemic persons by gross examination and objective analyses including examination under Woods lamp, magnification of digital photograph, and histologic changes to validate the age as per available history.
\end{abstract}

Method: This is an autopsy based prospective study over a period of 1 year (Feb 2015-Feb 2016),involving 50 cases of contusions conducted in Department of Forensic Medicine, Govt Medical College Calicut. The data obtained were analysed by SPSS software version 18. Comparison of different components, the level of correlation between various variables and significance of association were determined, and sensitivity and specificity of various method of analyses in determining the age of wounds were established.

Conclusion: Grossly,contusions were red $<24$ hours old, bluish black on day 2, greenish on day 3 and yellow on day 7 as was seen in magnified digital photograph.

There is increasing positive agreement between colour of wound assessed from magnified digital photograph and period of survival from day 1 to day 5-6 and decreases thereafter in normotensives, hypertensives and non diabetic subjects whereas it drops drastically after 7 days in diabetics.

The association between colour of contusion under Woods lamp and survival period increased from day 1 to reach maximum on 5-6 days.

There is significant positive association between presence of hypertension, as in diabetes, and histological delay in healing of contusions whereas no significant association was found with anemic status.

Keywords: Anemic; contusion; diabetic; digital photography; healing; histopathology; hypertensive; Woods lamp.

\section{Corresponding Author:}

\section{Dr. Nisha Nandakumar}

Assistant Professor, Department of Forensic Medicine and Toxicology, KMCT Medical College, Kozhikode e-mail: drnishanandakumar4n6@gmail.com Contact Number: 0091-9895584681/8921859545

\section{Introduction}

A wound is a disruption of the normal structure of tissues caused by the application of force to the body, the interpretation of which may have significant medico legal implications including the incrimination 
or exclusion of a suspect as the perpetrator of a crime. The evaluation of any tissue injury is thus an essential component of practice ofForensic Medicine.

The mechanical principles involved in production of wounds have been described by Moritz. ${ }^{16}$ Contusions are wounds characterized by effusion of blood into tissue spaces caused by forceful impact of blunt objects.Its colour changes reflect the natural healing process, though these changes donot occur uniformly andis modified by both systemic and local hostfactors like genetic disorders like Ehler Danlos syndrome, hormones, size of contusion, age and physique of the person and also presence or absence of diseases likediabetes, anemia, malignancy, drugs, malnutrition, obesity, systemic infection,status of liver functions, blood dyscrasias etc. ${ }^{25}$

The age of a contusion may be ascertained roughly from colour changes ${ }^{26,18}$ that commence at the periphery and extend inwards towards the centre from 18 to 24 hours after its infliction. ${ }^{15}$ Estimationof age of wound by visual inspection alone is subjective and susceptible to variation in perception, but previous studies have shown that it may be possible to determine age of wound by complementing the direct observation with magnified digital photography. ${ }^{14,12,23}$ These colour changes are due to the disintegration of the red blood cells and staining of the haemoglobin set free by the action of enzymes from tissues. It is red on the first day, appear blue, bluish black, brown or livid red dueto formation of haemosiderin during the next three days, become greenish due to the formation of haemotoin from the fifth to the sixth day, and yellow due to the formation of bilirubin from the seventh to the twelfth day. This yellow colour slowly fades till the $14^{\text {th }}$ or $15^{\text {th }}$ day when the skin regains its normalappearance. ${ }^{3,15}$

It is better to verify with microscopic examination and also other objective method of analysis since histologicalexamination alone may assist only a little in dating contusions because of the variations in the date at which the healing process develops. ${ }^{20,24}$

\section{Results and Discussion}

In the current study, on gross examination, the predominant colour of contusion with survival period $<24$ hours was red, bluish black from 2-3 days, greenishon day 3 ,yellowish on day 7 . All the contusions on day 10 were yellowish. These findings are in accordance with the observations made by Bernard Knight ${ }^{2}$ where contusions appeared red on first day, blue or bluish black in 2-4 days, greenish by $5^{\text {th }}$ to $6^{\text {th }}$ day and yellowish by 7-12 days of infliction.

Camps also found the contusions were red immediately after infliction; were greenish 4-5 days after infliction of injury and yellowish in 7-10days. ${ }^{7}$

Similar were the observations made by Dimitrova $\mathrm{T}$ and Georgieva $\mathrm{L}$ et $\mathrm{al}^{5}$ who found that bruises were predominantly red on day 1 , blue on day 3 , greenish colour was noted on day 4-6, yellow colour emerging on day 7 and dominant from day 7 to 14 .

Observations made in the current study were in complete agreement with the findings obtained by Adelson $^{1}$ and also byCamps. ${ }^{7}$

Polson and Gee similarly found that bruise was red up to 24 hours, purple black in 1-3 days, green till 7 days and yellow up to 2 weeks thereafter. ${ }^{19}$

Moritz A R found brown discolouration of contusions older than 24 hours, ${ }^{16}$ whereas Spitz W $\mathrm{U}$ and Fisher R S noticed brown colour by the end of first week, ${ }^{21}$ unlike in the current study where a specific brown discolouration was not found in contusion at any stage ofhealing.

Similar were the findingsobtained on magnification of digital photographs.T. Stephenson and Y. Bialas noted red colour in photograph of an injury $<1$ week old, and they found that shades of green and yellow suggest injury is atleast 24 to 48 hours old, ${ }^{23}$ whereas in the current study it was noted that red colour was seen predominantly in contusions $<24$ hours old, bluish black on days 2 and 3 .

Bariciak et $\mathrm{al}^{13}$ stated that the accuracy of ageing of a bruise to within 24 hours of its occurrence is less than $50 \%$. It was found by them that recent bruises showed colours of red, blue, purple and older bruises showed yellow, brown and green discolourations.

Histological analysis of contusions for correlations with survival period in the current study showed that in contusions $<24$ hours old, the predominant feature was infiltration of red blood cells into the wound.By day2 there was neutrophilic predominance, in 3days there was prominence of lymphocyteinfiltration.By 4 days or more presence of macrophages were noted and pigments were noted at the earliest on day5,collagen fibres from 6 days onwards and complete re-epithelisation was noted from day7. 
The earliest evidence of appearance of fibroblasts was on day 8 and a level of high density fibroblasts was attained by day10. Jayson and Payne found that neutrophils if found it denotes post infliction interval of approximately 15 hours upto several months after wound infliction. ${ }^{10}$ Macrophages were noted from 3 hours to 3 days. However Raekellio and Heplapfound only few lymphocytes in wounds aged 12 hours, ${ }^{20}$ whereas Betz P found spot like lymphocyte infiltrates at the earliest after about 1 week. $^{4}$

Ishida Y, Kimura A and Takayasu et $\mathrm{al}^{9}$ found that there were no fibrocytes detected in contusions of age less than 3 days. They were detected initially in wounds aged 4 days and the number increased with age of contusion. There was a maximum of fibrocytes during days 9-14. Their observation was that number of fibrocytes over 10 indicated wound age between 9 and 14 days.

There was excellent correlation between the period of survival and histopathological findings. There was increasing delay in histopathological evidence of healing of contusions subjects with survival period 6 days ormore.

In the present study, no significant association was found between the haemoglobin value and histopathological delay in healing of contusion.Pavlidis et al carried out a retrospective analysis of 89 patients and found that anemia was not associated with wound dehiscence. ${ }^{17}$

Khanbai et al found that decline in haemoglobin value had association with with poor wound healing. ${ }^{11}$

It has long been known historically that iron is essential for healthy skin, mucous membranes, hair and nails. The role of iron in the skin and cutaneous wound healing was studied by Wright and Richards et al. ${ }^{27}$ They found that anemia can lead to increased iron concentration in cells especially macrophages and this could have a detrimental effect on healing. Iron deficiency without inflammation is likely to affect one of later stages of wound healing such as remodeling. ${ }^{6}$

In this study, it was found that there is significant positive association between presence ofhypertension and histological delay in healing of contusion than by gross examination. Similar was the finding in diabetic cases.Ahmed and Mooar et al examined the influence of hypertension on the length of time required until a wound is dry. ${ }^{2}$ They found that the wounds of hypertensive patients tended to require approximately 2 days longer to dry than those of normotensive patients though precise mechanisms underlying the delay in wound healing were unknown. It could be because aspirin and other NSAIDs commonly used as cardioprotective medications have effects on the clotting cascade. ${ }^{22}$

Diabetes mellitus is associated with delayed healing as a consequence of microangiopathy. In adequate blood supply usually caused by arteriosclerosis or venous abnormalities that retard venous drainage also can cause impaired healing. Hormones such as glucocorticoids have anti inflammatory effects that influence various components of inflammation and inhibit collagensynthesis. ${ }^{25}$

Though it was stated by V.K. Hughes and N.E.I. Langlois et al that alternative light source was unable assist in determining the age of bruise in their study, ${ }^{8}$ it was found to delineate the subtle colour changes in the contusions of grossly greenish colour in the current study, which was in accordance with observations of Vogeley E, Pierce M.C and Bertocci G, who stated that the margins of the wound could be better visualized by thismethod. ${ }^{26}$ The association between colour of contusion by Woods lamp examination and survival period assessed by this study increased from day 1 to reach maximum on 5-6 days then declined. Kappa agreement test showed good agreement.

There was increasing correlation between colour of the contusion by magnification of digital photography with that of survival period till 5-6 days and decreased thereafter. There was moderate agreement byKappa agreement test.

There was increasing positive agreement between colour of wound assessed from magnified digital photograph and period of survival from dayl to day 5-6 and decreased thereafter in non diabetic subjects. Whereas in diabetic subjects the positive correlation dropsdrasticallyafter day7. There was moderate agreement between the colourof contusion by magnification of digital photograph and period of survival in non diabetic subjects while the agreement was poor in diabeticsubjects.

The maximum agreement between survival period and colour of contusion by Woods lamp examination was found on 5-6 days for non diabetic subjects. There was good agreement by Kappa agreement test. In 
diabetic subjects also it was maximum on 5-6 days, but the agreement waspoor.

There was moderate agreement between the colour of contusion by magnified digital photograph and survival period in normotensive subjects which was maximum on 5-6 days after sustaining the injury, as was in hypertensive subjects. There was no difference noted considering the hypertensive status of subjects of the study.

There was no difference in agreement considering colour of contusion by Woods lamp examination and period of survival with respect to hypertensive status of subjects.

\section{Conclusion}

- On gross examination, contusions were red when $<24$ hours old, bluish black on day2,greenishcolour appearedattheearliestonday 3 ,andyellowonday 7 .

- Histology of contusions <24hours showed red blood cells, neutrophils on day2, lymphocytes on day3, macrophages from day4, pigments from day5, collagen fibres from 6days, complete reepithelisation from day7, fibroblasts from day8, which increased in density on day 9 and 10 .

- There was excellent correlation between the period of survival, colour by gross examination and histopathologicalfindings.

- There was increasing histopathological delay in healing of contusions subjects with survival period 6 days ormore.

- There was no significant association between the haemoglobin value and histopathological delay in stage of healing ofcontusion.

- There was significant positive association between presence of hypertension and histological delay in healing of contusion than by grossexamination.

- There was positive correlation between presence of diabetes mellitus and the delay in healing of contusion by histopathology examination than by gross examination.

- There was increasing correlation between colour of the contusion assessed by magnification of digital photography with that of survival period till 5-6 days.
- There was increasing positive agreement between colour of wound assessed from magnified digital photograph and period of survival from day1 to day5-6 when it reaches the maximum and decreases thereafter in non diabetic subjects.

- In diabetic subjects the positive correlation drops drastically after day 7 .

- There was moderate agreement between the colour of contusion by magnified digital photograph and survival period in normotensive subjects which was maximum on 5-6 days, as was in hypertensivesubjects.

- By Woods lamp examination, the exact colour of the contusion could be precisely made out. $2 \%$ of greenish discolored contusion was found to be bluish black in colour and $4 \%$ of greenish coloured contusions were found to have a yellowish discolouration when examined under Woods lamp illumination.

- The association between colour of contusion when examined under Woods lamp illumination and survival period increased from day 1 to reach maximum on 5-6 days thendeclined.

- The age of contusions were determined, its correlation to various factors analysed, difference in rate of healing with respect to different disease conditions evaluated, and sensitivity and specificity of various method were assessed. It was concluded that an array of subjective and objective analyses can be used to establish the age ofwound and assess the rate of healing.

\section{Highlights:}

- Excellent correlation between age of contusion, gross and histology finding.

- No significant association between anemia and histological delay in healing.

- Significant positive association between hypertension and histological delay in healing.

- Positive correlation between diabetes mellitus and histological delay in healing.

- Increasing correlation between age of contusion and colour with digital photography and Woods lamp examinationtill 5-6 days. 
Table 1: Haemoglobin value and difference in stages of healing

\begin{tabular}{|c|c|c|c|c|c|}
\hline & & & Diffe & e category & \\
\hline & & & 2 or more days & 0 or 1 day difference & \\
\hline 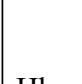 & $\begin{array}{l}0 \\
(>10 \mathrm{gm} \%)\end{array}$ & $\begin{array}{l}\text { Count } \\
\% \text { within } \mathrm{Hb}\end{array}$ & $\begin{array}{c}6 \\
18.2 \%\end{array}$ & $\begin{array}{c}27 \\
81.8 \%\end{array}$ & $\begin{array}{c}33 \\
100.0 \%\end{array}$ \\
\hline & $\begin{array}{l}1 \\
(<10 \operatorname{gm} \%)\end{array}$ & $\begin{array}{l}\text { Count } \\
\text { \% within } \mathrm{Hb}\end{array}$ & $\begin{array}{c}4 \\
23.5 \%\end{array}$ & $\begin{array}{c}13 \\
76.5 \%\end{array}$ & $\begin{array}{c}17 \\
100.0 \%\end{array}$ \\
\hline Total & & $\begin{array}{l}\text { Count } \\
\% \text { withinHb }\end{array}$ & $\begin{array}{c}10 \\
20.0 \%\end{array}$ & $\begin{array}{c}40 \\
80.0 \%\end{array}$ & $\begin{array}{c}50 \\
100.0 \%\end{array}$ \\
\hline
\end{tabular}

Table 2: Hypertension and different rates of healing

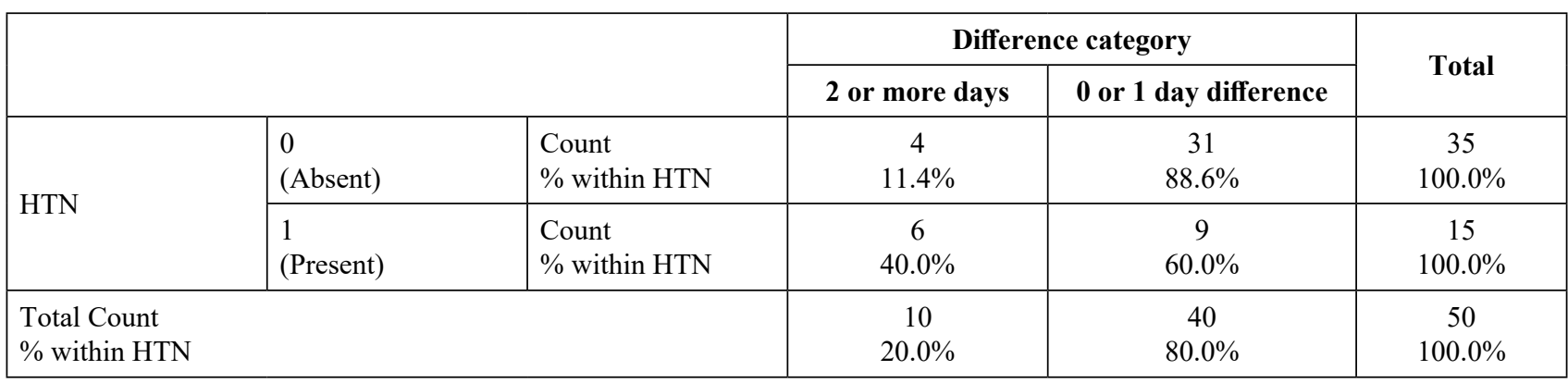

Table 3: Diabetes mellitus and difference in rates of healing

\begin{tabular}{|c|c|c|c|c|c|}
\hline & & & Differe & gory & \\
\hline & & & 2 or more days & 0 or 1 day & \\
\hline & $\begin{array}{l}0 \\
\text { (Absent) }\end{array}$ & $\begin{array}{l}\text { Count } \\
\% \text { within DM }\end{array}$ & $\begin{array}{c}1 \\
2.7 \%\end{array}$ & $\begin{array}{c}36 \\
97.3 \%\end{array}$ & $\begin{array}{c}37 \\
100.0 \%\end{array}$ \\
\hline Divi & $\begin{array}{l}1 \\
\text { (Present) }\end{array}$ & $\begin{array}{l}\text { Count } \\
\% \text { within DM }\end{array}$ & $\begin{array}{c}9 \\
69.2 \%\end{array}$ & $\begin{array}{c}4 \\
30.8 \%\end{array}$ & $\begin{array}{c}13 \\
100.0 \%\end{array}$ \\
\hline Total & & $\begin{array}{l}\text { Count } \\
\text { \% within DM }\end{array}$ & $\begin{array}{c}10 \\
20.0 \%\end{array}$ & $\begin{array}{c}40 \\
80.0 \%\end{array}$ & $\begin{array}{c}50 \\
100.0 \%\end{array}$ \\
\hline
\end{tabular}

Table 4: Colour of wound by digital photography and survival category

\begin{tabular}{|c|c|c|c|c|c|c|c|}
\hline & & & \multicolumn{4}{|c|}{ Survival category } & \multirow[b]{2}{*}{ Total } \\
\hline & & & $\begin{aligned} & 1.00 \\
< & 24 \mathrm{hrs}\end{aligned}$ & $\begin{array}{l}2.00 \\
2-4 d\end{array}$ & $\begin{array}{l}3.00 \\
5-6 d\end{array}$ & $\begin{array}{c}4.00 \\
7-15 d\end{array}$ & \\
\hline \multirow{4}{*}{$\begin{array}{l}\text { DP } \\
\text { colour }\end{array}$} & $\begin{array}{l}1 \\
\text { (Red) }\end{array}$ & $\begin{array}{l}\text { Count } \\
\% \text { within Survival category }\end{array}$ & $\begin{array}{c}6 \\
75.0 \%\end{array}$ & $\begin{array}{c}0 \\
.0 \%\end{array}$ & $\begin{array}{c}0 \\
.0 \%\end{array}$ & $\begin{array}{c}0 \\
.0 \%\end{array}$ & $\begin{array}{c}6 \\
12.0 \%\end{array}$ \\
\hline & $\begin{array}{l}2 \\
\text { (Bluish Black) }\end{array}$ & $\begin{array}{l}\text { Count } \\
\% \text { within survivalcategory }\end{array}$ & $\begin{array}{c}2 \\
25.0 \%\end{array}$ & $\begin{array}{c}11 \\
73.3 \%\end{array}$ & $\begin{array}{c}1 \\
11.1 \%\end{array}$ & $\begin{array}{c}1 \\
5.6 \%\end{array}$ & $\begin{array}{c}15 \\
30.0 \%\end{array}$ \\
\hline & $\begin{array}{l}3 \\
\text { (Green) }\end{array}$ & $\begin{array}{l}\text { Count } \\
\% \text { within Survivalcategory }\end{array}$ & $\begin{array}{c}0 \\
.0 \%\end{array}$ & $\begin{array}{c}4 \\
26.7 \%\end{array}$ & $\begin{array}{c}8 \\
88.9 \%\end{array}$ & $\begin{array}{c}10 \\
55.6 \%\end{array}$ & $\begin{array}{c}22 \\
44.0 \%\end{array}$ \\
\hline & $\begin{array}{l}4 \\
\text { (Yellow) }\end{array}$ & $\begin{array}{l}\text { Count } \\
\% \text { within survivalcategory }\end{array}$ & $\begin{array}{c}0 \\
.0 \%\end{array}$ & $\begin{array}{c}0 \\
.0 \%\end{array}$ & $\begin{array}{c}0 \\
.0 \%\end{array}$ & $\begin{array}{c}7 \\
38.9 \%\end{array}$ & $\begin{array}{c}7 \\
14.0 \%\end{array}$ \\
\hline \multicolumn{2}{|l|}{ Total } & $\begin{array}{l}\text { Count } \\
\% \text { within survival category }\end{array}$ & $\begin{array}{c}8 \\
100.0 \%\end{array}$ & $\begin{array}{c}15 \\
100.0 \%\end{array}$ & $\begin{array}{c}9 \\
100.0 \%\end{array}$ & $\begin{array}{c}18 \\
100.0 \%\end{array}$ & $\begin{array}{c}50 \\
100.0 \%\end{array}$ \\
\hline
\end{tabular}


Table 5: Colour of contusion by Woods lamp and survival category

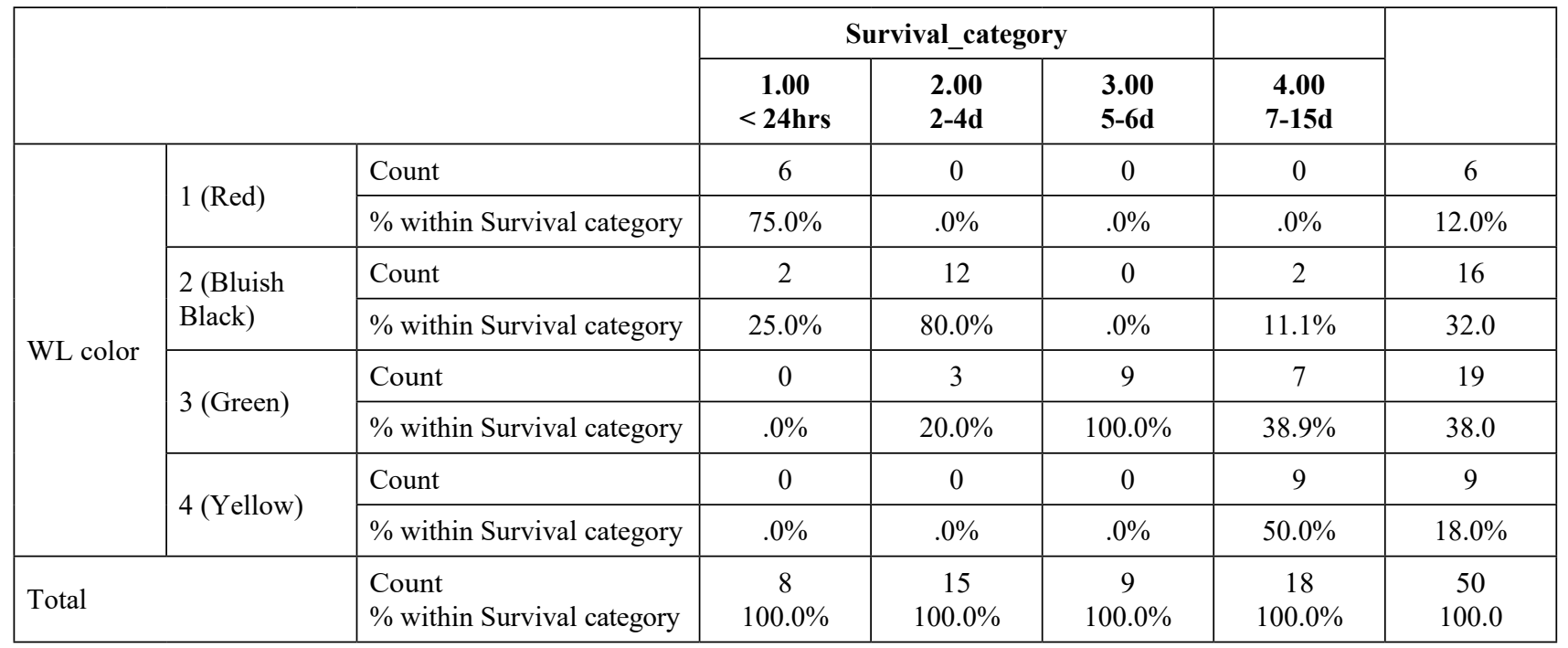

\section{List of Tables:}

1. Table 1 Haemoglobin value and difference in stages of healing

2. Table 2 Hypertension and different rates of healing

3. Table 3 Diabetes mellitus and difference in rates of healing

4. Table 4Colour of wound by digital photography and survival category

5. Table 5 Colour of contusion by Woods lamp and survival category

\section{Declaration of Interests: None}

Funding/Grants: None. This research did not receive any specific grant from funding agencies in public, commercial or not-for-profit sectors

\section{References}

1. Adelson L. The pathology of homicide. Springfield: Charles C Thomas; 1974:382-6.

2. Ahmed AA, Mooar PA, Kleiner M, Torg JS, Miyamoto CT. Hypertensive patients show delayed wound healing following total hip arthroplasty. PLoS One. 2011 Aug 11;6(8):e23224.

3. Bernard Knight, PekkaSukko. Forensic Pathology, $3^{\text {rd }}$ ed. Great Britain: Arnold;2004:138.

4. Betz P. Histological and enzyme histochemical parameters for the age estimation of human skin wounds. Int J Leg Med.1994;107:60-68.
5. Dimitrova T, Georgieva L, Pattichis C, Neofytou M. Qualitative visual image analysis of bruise age determination : a survey. ConfProcEng Med Biol Soc.2006.

6. Finberg KE. Regulation of systemic iron homeostasis. Current opinion in hematology. 2013 May 1;20(3):208-14.

7. Francis E Camps, Ann E Robinson, Bernard GB Lucas, Frederic C Thomas. Gradwohl's Legal Medicine, $3^{\text {rd }}$ ed. Great Britain: John Wright $\&$ Sons Ltd;1976:265.

8. Hughes VK, Ellis PS, Burt T, Langlois NE. The practical application of reflectance spectrophotometry for the demonstration of haemoglobin and its degradation in bruises. Journal of clinical pathology. 2004 Apr 1;57(4):355-9.

9. Ishida $\mathrm{Y}$, Kimura A. Takayasu $\mathrm{T}$, Eisenmenger W, Kondo T. Detection of fibrocytes in human skin wounds and its application for wound age determination. Int $\mathrm{J}$ Legal Med. 2009 Jul;123(4):299-304.

10. Jason Payne-James, Anthony Busuittil, William Smock. Forensic Medicine: Clinical and Pathological Aspects. London: Greenwich Medical Media Ltd; 2003:84.

11. Khanbhai ML, Wright JA, Hurel S, Richards T. Anaemia, inflammation, renal function, and the diabetic foot: what are the relationships?. The diabetic foot journal. 2012;15(4):150-8.

12. Langlois NEI, GreshamGA. The ageing of bruises, 
a review and study of the colour changes withtime. Forensic Sci Intl.1991;50: 227-238.

13. MaguireS, Mann M K, SilbertJ, KempA. Can you age bruises accurately in children? A systematic review. Arch Dis Child.2005;90:187-189.

14. Marie MJ Lecomte, Tim Holmes, Daniel P Kay, Joanne L Simons, Sue K Vintiner. The use of photographs to record variation in bruising response in humans. Forensic Science International. 2013;231:213-218.

15. Mathiharan K, Justice K Kannan, editors. Modi's Medical Jurisprudence and Toxicology, $24^{\text {th }}$ ed. Gurgaon: LexisNexis Publications, a division of Reed Elsevier India Pvt Ltd; 2012,Third Reprint2013:521.

16. Moritz A R,The Pathology of Trauma. Lea and Febiger, Philadelphia;1942:13-19.

17. Pavlidis TE, Galatianos IN, Papaziogas BT, Lazaridis CN, Atmatzidis KS, Makris JG, Papaziogas TB. Complete dehiscence of the abdominal wound and incriminating factors. The European journal of surgery. 2001 May 1;167(5):351-4.

18. Philling $\mathrm{M}$ L, Vanezis $\mathrm{P}$, Perret $\mathrm{D}$, Johnston A,Visual assessment of the timing of bruising by forensic experts. Journal of Forensic and Legal Medicine.2010; 17:143-149

19. Polson CJ, Gee DJ. The essentials of forensic medicine, $4^{\text {th }}$ Ed. Oxford: Pergamon Press; 1984:97-105.
20. Raekallio J. Histological estimation of the age of injuries. In: Perper JA, Wecht CH, eds. Microscopic diagnosis in forensic pathology. Springfield, Illinois: Charles C Thomas;1980:3-16.

21. Spitz WU, Fisher RS. Medico legal investigation of death. Springfield, Illinois: Charles C Thomas;974

22. Steiner M. Vitamin E, a modifier of platelet function: rationale and use in cardiovascular and cerebrovascular disease. Nutrition reviews. 1999 Oct 1;57(10):306-9.

23. StephensonT, BialasY. Estimation of the age of bruising. Arch Dis Child.1996;74: 53-55.

24. Thornton RN, Jolly RD. The objective interpretation of histopathological data: an application to the ageing of ovine bruises. Forensic Sci Int. 1986 Jul 31; 31(4):225-39.

25. Vinay Kumar, Abdul K Abbas, Nelson Fausto. Robbins and Cotran Pathologic Basis Of Disease, $7^{\text {th }}$ ed. Philadelphia: Saunders; 2004:114- 115.

26. Vogeley E, Pierce M C, Bertocci G. Experience with Wood lamp illumination and digital photography in the documentation of bruises on human skin. Arch PaediatrAdolesc Med.2002 Mar;156(3):265-8.

27. Wright JA, Richards T, Srai SK. The role of iron in the skin and cutaneous wound healing. Frontiers in pharmacology. 2014 Jul 10;5:156. 